\title{
Psychometric Evaluation of the Gratitude Toward the Organization Scale
}

\author{
Marcin Wnuk ${ }^{1}$
}

Submitted: 10.01.20. Accepted: 4.08.20

\section{Abstract}

Purpose: Gratitude is an interdisciplinary concept frequently explored in positive psychology, which recognizes gratitude as one of the seven transcendent character forces that promote well-being and life satisfaction. The purpose of the conducted research was to develop the concept of gratitude toward the organization and prepare a tool to study this phenomenon.

Methods: The study was cross-sectional. Participants were 802 employees from various organizations.

Results: The Gratitude Toward the Organization Scale has a good internal consistency (Cronbach's $\alpha$ was 0.91 . Factor analysis confirmed the two-factor structure of this tool. The dimensions of gratitude toward the organization are distinguished as: (1) gratitude as a commitment to reciprocity and (2) gratitude as a moral norm. The construct validity of this measure was confirmed. Gratitude toward the organization correlated positively with job satisfaction, affective commitment to the organization, organizational justice, and perceived organizational and supervisor support, while being negatively correlated with intent to leave the organization.

Conclusions: The obtained results confirm very good psychometric properties of the Gratitude Toward the Organization Scale as a valid and reliable measure for studying the gratitude of employees, which can be successfully used by researchers in Poland.

Keywords: gratitude toward the organization, measure, reliability, social exchange, reciprocity norm.

JEL: J28; J63; M12

\footnotetext{
1 Adam Mickiewicz University in Poznań, Department of Work and Organizational Psychology, e-mail: marwnuk@wp.pl, https://orcid. org/0000-0002-3784-5870. 


\section{Introduction}

Gratitude is a significant social phenomenon from the viewpoint of interpersonal relations. According to Oxford English Dictionary, gratitude comes from the Latin word gratia, meaning "grace, graciousness, gratefulness," and gratia and is defined as "the quality or condition of being thankful; the appreciation of an inclination to return kindness." In this context, gratitude is seen as a specific attitude toward another person that constitutes a response to a received good, which implies that the received good needs to be noticed, it activates specific positive emotions and internal arousal, and a motivation to reciprocate caused by the feeling of being endowed and wanting to requite.

In psychology, gratitude is treated as an emotion (Maslow, 1968; Smith, 1976; Lazarus, McCullough et al., 2001), a moral attitude, a character strength (Park, Peterson and Seligman, 2004), a habit, a personality trait, or a state and mechanism of coping with stress (McCullough, 2003).

Within the field of positive psychology, gratitude as a character strength, being the most elementary and positive manifestation of human functioning (Park, Peterson and Seligman, 2004) - along with hope - creates enthusiasm, the appreciation of beauty and perfection, humor, spirituality, and forgiveness, a virtue associated with a transcendence that manifests itself in the ability to see beyond everyday concerns (Seligman, 2002).

According to McCullough et al. (2001), gratitude is a moral emotion that plays three key functions: of a moral barometer, moral motivator, and moral reward. Gratitude serves as a moral barometer after receiving help; it is the stronger the more intentional (and not accidental) is the perceived effort of the granter, and the greater is the value of the favor and costs on the part of the granter. Gratitude as a moral motivator encourages the receiver to reciprocate the received good. Finally, as a moral reward, it increases the probability of helping the receiver more in the future thanks to gratitude expressed by the person which, at the same time, positively influences the granter's motivation to provide more help.

Gratitude can be looked into from the perspective of a moral norm (see Buksik, 2002) that constitutes a specific kind of generalized obligation shaped on the basis of individual situations and experiences in a person's life, thanks to which the individual builds a generalized belief about the need to be grateful, which makes it easier for the person to notice situations in her/his life for which s/he should be grateful. 
On the basis of the concept put forward by Maslow, who treats gratitude as a moral emotion (Maslow, 1968), we may state that the moral norm of gratitude becomes internalized when the person begins to see her/his own existence as a gift, something exceptional, unique, and inalienable. Then, experiencing admiration, respect, and worship, the person feels as if s/he does not deserve it, which triggers in the individual the experience of gratitude both toward God, fate, nature and toward another person, the past, the world; therefore, toward all this that participated in achieving by the person the present desired state. It is something that manifests itself not only in elements characteristic of religious experiences, such as praising, worshiping, or admiring, but also in an internal readiness to do something good for the surrounding world as an act of reciprocating the received gift (Maslow, 1968).

The moral norm of gratitude, as any other moral norm as delineated by Kępiński (1987), in its constitutional layer can be rooted in the person's psychological structure via nature as a provider of a natural moral order that - thanks to conscience - enables the differentiation between good and evil. The other two planes that form moral norms are: moral rules that become internalized in the period of early childhood and everyday experiences that can either strengthen or modify the effect of norms on the person's functioning. According to the above, nature as the main source of the norm of gratitude can be identified by non-religious individuals - who define themselves as spiritual - with a force majeure (a superior power), whereas by religious people it can be identified with God.

In many religious systems, gratitude is treated as one of the most crucial and desired virtues (Emmons and Crumpler, 2000). According to the results of studies conducted by Emmons and Kneezel (2005), indicators of both public and private manifestations of religiousness were positively correlated with a disposition to be grateful and with the feeling of gratitude. Other studies show that gratitude as a trait is positively correlated with internally motivated religiousness and negatively correlated with religiousness motivated externally (Watkins et al., 2003). The results of studies conducted by Krause and Hayward (2015) enabled me to describe a mechanism of shaping gratitude toward God on the basis of engagement in religious practices. According to the obtained results, more frequent participation in services strengthens religious engagement, on the basis of which takes shape the virtue of humility. In turn, this virtue enables people to experience greater empathy toward other people, which is followed by a deeper sense of religious meaning of life, leading in consequence to greater gratitude toward God. Religious individuals can perceive gains as gifts from God, who is to be the initial cause of all good (Watkins et al., 2003). Gratitude toward God can become generalized over other elements of nature, both animate and 
inanimate. It can be expressed both toward someone and something - i.e., a person, nature, the universe, or an animal (Solomon, 1977; Teigen, 1997) - but also for something; for instance, for living conditions, for what one has received, experienced, or learned, for spiritual resources, for what has been given or has been forgiven, for one's internal traits, future positive experiences, welfare, or blessings (Friedman, 1989). Gratitude reflects both an attitude toward the giver and the gift (Harned, 1997). Expressed by an employee toward an organization in which the person works (Wnuk, 2017a), gratitude can pertain to gaining there, e.g., new professional competencies, making new acquaintances in the workplace, fair treatment, integrity and openness of the employer, atmosphere in the workplace, opportunities associated with professional development, promotion.

Gratitude plays an important role for employee attitude as social support (Hu and Kaplan, 2014), altruism (Dik et al., 2014), prosocial organizational behaviors (Michie, 2009; Grant and Gino, 2010), organizational citizenship behaviors (McCullough et al., 2001; Spence et al., 2013), along with efficiency, productivity, and job performance (Grant and Wrześniewski, 2010).

For some authors, gratitude is a significant organizational well-being and health indicator (Di Fabio, Palazzeschi and Bucci, 2017), which can be measured both on an individual and collective level (Fehr et al., 2017).

According to Di Fabio et al. (2017) recommendations, the aim of this study was to create a measure of gratitude in organizational contexts based on authorship conception of gratitude toward the organization on the individual level in contrast to multilevel constructs of episodic gratitude, persistent gratitude, and collective gratitude as defined by Fehr et al. (2017) as well as collective level emphasized by Müceldili et al. (2015). Research regarding employee gratitude is a very important goal in Human Resources Management practice for improving employee well-being (Watkins et al., 2003; Emmons and McCullough, 2003), organizational well-being (Di Fabio, Palazzeschi and Bucci, 2017), promoting organizational citizenship behaviors (McCullough et al., 2001; Spence et al., 2013), building trust among employees, improving productivity and job performance (Grant and Wrześniewski, 2010), developing management and leadership based on gratitude (Michie, 2009), and implementing organizational culture based on gratitude. 


\section{Gratitude Toward the Organization Concept}

The organizational support theory (Eisenberger, 1986) observes relations between the employee and the organization from the perspective of social exchange (Blau, 1964) based upon the rule of reciprocity (Gouldner, 1960). According to the assumptions of this theory, employee perception of the organization as caring about her/his good and supportive will prompt in him/her - in accordance with the rule of reciprocity (Gouldner, 1960) - a desire to reciprocate and act for the benefit of the organization. Gratitude is a commitment (Berger, 1975; Meilaender, 1984) that has a moral character (Schimmel, 1997) as something that we owe to somebody, and on whom or what our well-being depends. In the context of employee work-related functioning, one's professional welfare and sense of fulfillment in what one does largely depend on the employer who can either create optimal conditions for the employee's professional functioning, development, and realization of socio-emotional needs in the workplace - or not. If in employee perception the organization provides support to her/him and cares about her/his well-being, then according to the principles of social exchange and the rule of reciprocity, the person will take care about the welfare of the organization by fulfilling her/his duties properly, identifying with business objectives of the company, and engaging in the company's further development.

One of the crucial functions of gratitude is shaping and consolidating social bonds. According to Simmel (1950), as a consequence of the socialization process, gratitude constitutes a cognitive-emotional supplementation of mutual commitments, reminding people about the need to reciprocate. It results from the fact that formal social structures, such as law or agreements, do not suffice to regulate and assure mutuality in interpersonal relations (Simmel, 1950). Smith (1976) also considers gratitude to be the basic social emotion that decides about the state of social balance, predisposing people to treat favorably those who intentionally do them good.

An interesting multilevel model of gratitude in organizations was presented by Fehr et al. (2017). According to this model, gratitude consists of three elements: episodic gratitude at the event level, persistent gratitude at the individual level, and collective gratitude at the organizational level. Episodic gratitude is "a feeling of appreciation in response to an experience that is beneficial to, but not attributable to, the self" (Fehr et al., 2017, p. 363). Persistent gratitude is considered "a stable tendency to feel grateful within a particular context” (Fehr et al., 2017, p. 363). Collective gratitude is defined as "persistent gratitude that is shared by the members of an organization" (Fehr et al., 2017, p. 364). Thus, episodic gratitude is related to organizational citizenship, persis- 
tent gratitude to well-being, and collective gratitude to corporate social responsibility (Fehr et al., 2017).

On the basis of the literature review, I propose a definition of gratitude toward the organization based on two crucial aspects: gratitude as a moral norm and gratitude as a commitment to reciprocity. In my opinion, gratitude toward the organization is a moral attitude composed of the moral norm of being grateful and cognitive-emotion -al-motivational aspects that decide about the need to reciprocate, in the form of commitment to reciprocity. The moral norm of gratitude has a general character, and its scope covers various objects and phenomena, including organizations (employers), being a generalized conviction that one has to be and should be grateful. It is a relatively stable disposition to react with gratitude to any received good, regardless of who or what is its source. Gratitude as a moral norm is similar to Fehr et al.'s (2017) persistent gratitude. Both of these conceptualizations refer to the tendency to be grateful - revealed on the individual level - and rely on the interpretation of events and situations as things that deserve gratitude. The difference between them is that according to the first approach disposition, to react with gratitude derives from the internalization of gratitude as a moral norm, which is a consequence of the socialization process and does not have emotional character. On the other hand, persistent gratitude has an emotional character based on the activation of emotion schemas, which predispose individuals to experience gratitude as an emotion emerging from episodic gratitude at the event level. Persistent gratitude is a proneness to notice good or benefits even if they are not of an open or direct character. This enables perceiving reality as something positive and good, toward which one should be grateful. Persistent gratitude allows one to experience positive emotions, such as admiration, pride, or hope, which motivates to reciprocity. According to the broaden-and-build theory of positive emotions, "experiences of positive emotions broaden people's momentary thought-action repertoires, which in turn serves to build their enduring personal resources" (Fredrickson, 2001, p. 218). Positive emotions like gratitude have a "broadening effect" on the momentary thought-action repertoire. They allow us to discard automatic responses and, instead, look for creative, flexible, and unpredictable new ways of thinking and acting (Fredrickson, 2004). This facilitates perceiving reality, experiences, and life events as an opportunity to grow and develop spiritually.

The cognitive-emotional-motivational component of the attitude of gratitude toward the organization in the form of commitment to reciprocity manifests itself in an emotional reaction that arises from the perception of gaining or experiencing a concrete good, in a positive attitude toward its source, and in a motivation to reciprocate it, conditioned and reinforced culturally by the rule of reciprocity (Gouldner, 1960), 
which engenders in the bestowed individual a specific kind of internal tension that can be relieved by means of reciprocating and repaying for the obtained gift.

The key difference between the moral norm of gratitude and the commitment to reciprocity consists in that the moral norm has a general character, it does not refer to any specific situation or event associated with the job or the organization, and it is relatively independent of the rule of reciprocity (Gouldner, 1960). The moral norm makes it easier for the person who internalized this norm to notice the concrete good received from the organization.

Thus, we may state that the moral norm functions as a facilitator in strengthening the attitude of gratitude toward the organization and in shaping the sense of commitment toward the organization. Moreover, as opposed to commitment to reciprocity, the moral norm only to a small extent depends on the attitude of the organization toward the employee that can result in a situation in which the employee is grateful to the organization even when it is difficult for her/him to find the rationale for possessing such an attitude. Internalizing this moral norm will make it easier for the person to find such an element for which s/he can be grateful, it will reduce the level of criticism in the evaluation of organization, and it will be conducive to conducting a re-interpretation of the given event or situation.

\section{Methodology}

\section{Research Sample}

The applied questionnaire was anonymous and was distributed by a psychologist. All respondents expressed consent to partake in the study. From the total number of 1000 questionnaires distributed, 802 were filled in by employees from various organizations. The mean age of participants was 28.11 years $(\mathrm{SD}=9.51$ ), the mean work seniority was 7.36 years ( $\mathrm{SD}=9.02$ ), whereas the mean work seniority in the current workplace was 4.13 years $(\mathrm{SD}=6.67)$. The research sample was composed in $60.4 \%$ of women and in $39.6 \%$ of men. Few respondents $(0.03 \%)$ had primary education, occupational education $2.10 \%$, secondary education $50.80 \%$, whereas $46.80 \%$ of participants possessed higher education. Nearly half of the investigated individuals (38.6\%) were low-level employees, $38.6 \%$ were specialists, $9.1 \%$ were employed on lower-level managerial positions, $9.2 \%$ on mid-level managerial positions, and $4.5 \%$ of the respondents held higher-level managerial positions. 


\section{Research Tools}

To assess the validity of Gratitude Toward the Organization Scale, some tools involved the reciprocity norm. I assumed that gratitude as a commitment to reciprocity is more related do organizational justice, perceived organizational and supervisor support, job satisfaction, and the intention to leave the organization than gratitude as a moral norm, as an aspect of gratitude toward the organization independent of the reciprocity norm. For the verification of the discriminant validity of Gratitude Toward the Organization Scale, this measure was correlated with affective organizational commitment as a most similar construct. I assumed that the value of correlation coefficient will not be stronger than moderate, which will be proof that this is not the same construct.

In order to verify organizational justice, I applied the Polish version of the Organizational Justice Scale (Wnuk, 2017a). The tool is composed of three dimensions: distributional justice, procedural justice, and interpersonal justice. To questions pertaining to distributional justice respondents replied on a five-point scale ranging from "very unjustly" to "very justly." The reliability of this scale, measured with the use of Cronbach's coefficient alpha, was $\alpha=0.93$. To questions about procedural and interpersonal justice respondents answered on a five-point scale ranging from "I strongly disagree" to "I strongly agree." The reliability of the interpersonal justice scale was $\alpha=0.90$, whereas of the procedural justice scale was $\alpha=0.85$.

To examine organizational commitment, I applied questions from the Polish version of the Organizational Commitment Scale by Allen and Meyer (Wnuk, 2017b). The tool consists of three dimensions of organizational commitment that measure three components of a person's psychological commitment to the organization: affective, normative, and continuance. In the present study, four questions pertaining to affective organizational commitment were used. The reliability of the applied tool, measured with the use of Cronbach's alpha, was $\alpha=0.78$.

The intention to leave the organization was measured with the use of a tool that included three questions (Lance et al., 1989). The respondents replied on a five-point Likert scale ranging from "I strongly disagree" to "I strongly agree." The reliability of the measure was $\alpha=0.95$.

In order to verify perceived organizational support (POS), I applied the Polish version of the Review of Perceived Organizational Support (Wnuk, 2017c), consisting of eight questions. The respondents gave their answers on a five-point scale ranging from 
"I strongly disagree" to "I strongly agree." The tool consists of one factor, and its reliability is $\alpha=0.89$.

Perceived supervisor support (PSS) was measured with the use of the Perceived Supervisor Support Scale (Eisenberger et al., 1986) that consists of three questions. The investigated individuals responded on a five-point scale ranging from "I strongly disagree" to "I strongly agree." The reliability of this measure was $\alpha=0.91$.

Job satisfaction was measured with the use of the statement "I generally like working here." The participants marked their response on a seven-point scale ranging from "I strongly disagree" to "I strongly agree."

\section{The Construction of the Gratitude Toward the Organization Scale}

The literature offers different questionnaires to measure gratitude. Most of them are multidimensional (Watkins et al., 2003; Adler and Fagley, 2005; Morgan et al., 2017), but they are not located in the organizational context measuring workplace-specific gratitude.

In the Polish research practice, the GQ-6 questionnaire created by McCullough et al. (2002) is applied to investigate gratitude, whose adaptation was prepared by Kossakowska and Kwiatek (2014). The main weak point of this tool is its unsatisfactory content validity and the fact that it refers to a general tendency to react with gratitude, so the application of this measure to investigating gratitude toward a specific source - in this case, toward the organization (employer) - is significantly limited.

On the basis of my concept of gratitude toward its particular source, I prepared a list of 40 statements among which one had the form of a negative sentence. Answers to these questions were given on a five-point Likert scale ranging from "I strongly agree" and "I agree," through "It is difficult to say," to "I disagree," and "I strongly disagree."

In the next step, items of the questionnaire were subjected to language and content verification by a competent judge (a psychologist) and students of the fifth year of psychology. As a result, the initial version of the tool, consisting of 14 statements, has been developed. 


\section{Results}

\section{Factor Analysis}

Obtained data was divided into two equal samples, 401 participants each. In the first sample, I conducted the Exploratory Factor Analysis (EFA). In the second sample, I employed the Confirmatory Factor Analysis (CFA). The second sample was used to verify the theoretical consistency of Gratitude Toward the Organization Scale.

The exploratory factor analysis of the Gratitude Toward the Organization Scale was tested using the principal component method with Promax rotation, and then by performing structural equation analysis using the maximum likelihood method.

I included those test items in the final version of the scale that loaded strongest the distinguished factors of the scale. In the latter case, after conducting the factor analysis, the load value of 0.6 was accepted as the critical value.

In consequence, I obtained 12 statements, among which four referred to the dimension of gratitude as a moral norm, and eight pertained to the dimension of gratitude as a commitment to reciprocity. Particular statements from the dimension of commitment to reciprocity loaded this factor from 0.60 to 0.88 , whereas in the case of gratitude as a moral norm, it was 0.77 to 0.9 (Table 1).

Because of the acceptance level of load value at 0.6 , only one statement among the final eight statements regarding gratitude as a moral norm was the indicator of motivational aspect, four reflected the emotional aspect, and three revealed the cognitive aspect.

The remaining statements were not included in the final version of the Gratitude Toward the Organization Scale either due to their low factor loadings or low discrimination power; manifested in loading the two distinguished factors to a comparable degree.

The Kaiser-Meyer-Olkin test for sampling adequacy - which indicates the possible proportion of the total variance explained - gave the result of 0.889 , which meant that sampling was satisfactory. The Bartlett's test of sphericity - which determines the degree of correlation between test items - showed that the sample was properly composed $\left(\mathrm{Chi}^{2} \approx 2486.800, \mathrm{df}=66, \mathrm{p}<0.01\right)$. The conducted factor analysis using the method of principal components with Promax rotation revealed the two-component structure of the prepared tool. Distinguished factors explained $62.68 \%$ of the variance 
of this tool. The first component explained $42.65 \%$, while the second $20.02 \%$ of the variance.

Table 1. Factor loadings in the Gratitude Toward the Organization Scale $(\mathrm{N}=401)$

\begin{tabular}{|c|c|c|}
\hline \multirow{2}{*}{ Statement } & \multicolumn{2}{|c|}{ Factor } \\
\hline & 1 & 2 \\
\hline I feel grateful to my organization/company. & 0.674 & 0.265 \\
\hline I have learned a lot while working in this organization/company. & 0.730 & 0.222 \\
\hline I have gained a lot of valuable experiences while working here. & 0.706 & 0.264 \\
\hline I am glad that I could get to such a nice organization/company. & 0.607 & 0.262 \\
\hline I feel obliged to the organization for everything I have received from it. & 0.602 & -0.123 \\
\hline $\begin{array}{l}\text { I am grateful to the organization/company for the possibility to meet } \\
\text { many valuable people. }\end{array}$ & 0.853 & -0.230 \\
\hline I have received a lot while working here. & 0.883 & -0.191 \\
\hline I feel proud that I work in this organization/company. & 0.789 & -0.182 \\
\hline $\begin{array}{l}\text { I think that everyone should be grateful for what s/he receives from } \\
\text { the organization/company, even if it is not always something expected. }\end{array}$ & -0.009 & 0.833 \\
\hline $\begin{array}{l}\text { Gratitude toward the organization/company is a natural and normal } \\
\text { reaction, regardless of circumstances. }\end{array}$ & -0.064 & 0.902 \\
\hline One should be grateful for everything in life. & -0.073 & 0.770 \\
\hline $\begin{array}{l}\text { I do not understand people who are not grateful to their employers } \\
\text { because I think that everybody deserves to experience gratitude. }\end{array}$ & -0.097 & 0.857 \\
\hline
\end{tabular}

Source: own elaboration.

In order to confirm the content validity of the obtained version of the scale, I conducted a confirmative analysis using the method of highest probability with the Amos program. To verify the model, I applied the following model fitness indicators: Normed Fit Index (NFI), Goodness of Fit Index (GFI), Comparative Fit Index (CFI), and Root Mean Square Error of Approximation (RMSEA).

The obtained values of RMSEA $=0.038$ (90\%: 0.017; 0.056), NFI $=0.980, \mathrm{GFI}=0.976$, $\mathrm{CFI}=0.993$, and $\mathrm{Chi}^{2}$ statistics $\left(\mathrm{Chi}^{2}\right.$ statistic value $\left.-\mathrm{CMIN}\right)=56.69 ; \mathrm{df}=36 ; \mathrm{p}=$ $0.001,(\mathrm{CMIN} / \mathrm{DF}=1.57)$ confirmed a very good fit of the model. Normed Fit Index (NFI) exceeded the satisfactory level of 0.9, GFI - 0.9 and CFI - 0.93 (Byrne, 1994). 
Moreover, the value of the RMSEA indicator was lower than the level of 0.05 that is considered to be ideal (Steiger, 1990).

\section{Theoretical Consistency}

As criteria for the construct validity of the Gratitude Toward the Organization Scale, I acknowledged its relationships with such variables as perceived organizational and supervisory support, organizational justice, affective organizational commitment, job satisfaction, and intention to leave the organization. I assumed that due to the rule of reciprocity (Gouldner, 1960) as the key element in social exchange (Blau, 1964), the dimension of gratitude as a moral norm - in comparison to the dimension of gratitude as a commitment to reciprocity - will correlate to a much lesser extent with the support received from the organization and supervisor, organizational justice, along with the attitude toward the organization measured with the use of job satisfaction, affective organizational commitment, and intention to leave the organization.

In Table 2, I provide the values of correlation coefficients between the dimensions of the Gratitude Toward the Organization Scale and the measures applied to the verification of its construct validity.

Table 2. Values of Pearson correlations between Gratitude Toward the Organization Scale and measures used to verify theoretical validity $(\mathrm{N}=401)$

\begin{tabular}{|c|c|c|c|}
\hline & $\begin{array}{c}\text { Gratitude Toward } \\
\text { the Organization } \\
\text { Scale }\end{array}$ & $\begin{array}{l}\text { Gratitude } \\
\text { as a commitment } \\
\text { to reciprocity }\end{array}$ & $\begin{array}{c}\text { Gratitude } \\
\text { as a moral norm }\end{array}$ \\
\hline Gratitude as a commitment to reciprocity & $0.93 * *$ & & \\
\hline Gratitude as a moral norm & $0.77 * *$ & & \\
\hline Intention to quit & $-0.38 * *$ & $-0.40 * *$ & $-0.20 * *$ \\
\hline Affective organizational commitment & $0.56 * *$ & $0.54 * *$ & $0.39 * *$ \\
\hline Job satisfaction & $0.40 * *$ & $0.43 * *$ & $0.19 * *$ \\
\hline Perceived supervisor support & $0.40 * *$ & $0.42 * *$ & $0.22 * *$ \\
\hline Perceived organizational support & $0.44^{* *}$ & $0.47 * *$ & $0.24^{* *}$ \\
\hline Procedural justice & $0.34 * *$ & $0.36 * *$ & $0.18 * *$ \\
\hline Interpersonal justice & $0.32 * *$ & $0.36 * *$ & $0.14 * *$ \\
\hline Distributive justice & $0.29 * *$ & $0.30 * *$ & $0.15^{* *}$ \\
\hline
\end{tabular}




\begin{tabular}{|l|c|c|c|}
\hline Age & 0.02 & -0.01 & 0.06 \\
\hline Overall work seniority & 0.03 & 0.01 & 0.06 \\
\hline Seniority in the current workplace & -0.02 & -0.04 & 0.03 \\
\hline Education & 0.01 & 0.05 & -0.07 \\
\hline Position held in the organization & 0.01 & -0.02 & 0.05 \\
\hline
\end{tabular}

Note: ${ }^{*} p \leq 0.05,{ }^{* *} p \leq 0,01$.

Source: own elaboration.

Furthermore, I checked whether gender differentiated the employees in respect of gratitude toward the organization. The obtained results show that women and men differ from each other neither in respect of the level of gratitude toward the organization $(t=0.23, p=0.81)$ nor in respect of its two components, i.e. gratitude as a moral $\operatorname{norm}(t=-1,10 p=0.27)$ and gratitude as a commitment to reciprocity $(t=0.93, p=0.35)$.

\section{Internal Consistency}

The internal consistency of particular scales of the questionnaire was investigated using the Cronbach's $\alpha$ coefficient. The internal consistency of the two dimensions of the tool turned out to be satisfactory. Gratitude as a commitment to reciprocity in the first sample was 0.91 and in the second sample -0.91 , whereas gratitude as a moral norm respectively in the first sample was 0.85 and in the second sample -0.82 . For the entire Gratitude Toward the Organization Scale, Cronbach's $\alpha$ coefficient in the first sample was 0.9 and in the second sample 0.9 .

\section{Discussion}

The Gratitude Toward the Organization Scale proved to have satisfactory psychometric properties. In contrast to the three dimensions measure of Watkins et al. (2003) and the eight dimensions solution of Adler and Fagley (2005), factor analysis confirmed the two-factor structure of this tool.

The first dimension of the Gratitude Toward the Organization Scale pertains to gratitude as a moral norm, based on a generalized conviction that one should be grateful for anything good experienced in life and work. The second dimension - simultaneously of cognitive, affective, and motivational character - refers to gratitude understood as a commitment to reciprocity, which is based on the rule of reciprocity that com- 
mands people to requite good or other benefits received from or through the mediation of another person (see Gouldner, 1960).

Thus, the conducted study confirmed the very good internal consistency of the Gratitude Toward the Organization Scale.

The construct validity of the scale was also confirmed. As anticipated, gratitude as a moral norm correlated weakly with distinguished indicators of employee evaluation of the organization's intentions, such as perceived supervisor and organizational support or organizational justice. At the same time, organizational justice, perceived supervisor, and organizational support were moderately related to gratitude toward the organization as a commitment to reciprocity.

Analogous results were observed in the case of employee attitude toward the organization expressed by job satisfaction, affective organizational commitment, and intention to leave the organization. Correlations of these variables with gratitude as a moral norm were much weaker than their relationships with the dimension of gratitude as a commitment to reciprocity.

The obtained results demonstrate that the dimension of gratitude as a moral norm is to a significant extent regardless of whether employees believed the organization and its personification - the supervisor (Levinson, 1965) - cares about and treats her/him fairly. On the contrary, in the case of gratitude as a commitment to reciprocity, employee perception of support from the organization and supervisor - and their appraisal of organizational justice -largely decide about the level of employee gratitude toward the organization. In the presented context and according to the rule of reciprocity (Gouldner, 1960) that is the essence of social exchange (Blau, 1964), affective commitment and intention to leave the organization can constitute an expression of compensation for the good received from the organization. The results of studies conducted by Wnuk (2017d; 2019) are consistent with the above conclusions. These previous studies proved that perceived supervisor and organizational support have a positive impact on gratitude as a commitment to reciprocity, indirectly improving affective commitment to the organization.

The dimension of gratitude as a moral norm seems to be mostly independent of social exchange (Blau, 1964) and its underlying rule of reciprocity (Gouldner, 1960), whereas the dimension of gratitude as a commitment to reciprocity appears to be determined by this rule of social life. 
The source of gratitude as a commitment to reciprocity, which indirectly influences job satisfaction, is employee spirituality, both with reference to its secular dimension - expressed in one's attitude toward co-workers and the organization - and to its religious aspect in the form of one's attitude toward God or another force majeure (Wnuk, 2018). Furthermore, for Van Cappellen et al. (2016) gratitude is an emotion like love, dread, and peace, mediated by religiousness, spirituality, and well-being and measured by life satisfaction and optimism.

Women did not differ from men in the level of gratitude toward the organization. Work seniority, seniority in the current workplace, age, education, and position in the organization did not correlate with gratitude toward the organization or either dimension of this scale.

The conducted studies carry a number of theoretical and practical implications. They confirm the two-factor character of the Gratitude Toward the Organization Scale, its satisfactory internal consistency and construct validity. The achieved results confirmed the positive role of gratitude toward the organization for employee occupational well-being measured by job satisfaction, affective organizational commitment, and intention to leave the organization. We should emphasize that gratitude toward the organization positively influences social exchange between employees and supervisors, but also between employees and organizations, through its positive impact on employee perception of organizational justice, organizational support, and supervisor support. These results can be explained based on Fredrickson's broaden-and-build theory (Fredrickson, 2001). Consistent with this theory, research indicates that gratitude increases trust in others and helps to build and reinforce social bonds (Dunn and Schweitzer, 2005; McCullough et al., 2001), but also improve well-being (Watkins et al., 2003; Emmons and McCullough, 2003).

The above research results prove that the Gratitude Toward the Organization Scale can be successfully applied to examining employees from Poland. From the selection and recruitment-related perspective, the results constitute an incentive to hire candidates who manifest a high level of gratitude toward the organization as an important element of shaping employee well-being and their positive attitude toward the organization. From the perspective of creating a human resources strategy, the results emphasize the need to make employees aware of what they receive from the organization and build gratitude as social resources that can lead to altruism (Dik et al., 2014), prosocial organizational behaviors (Michie, 2009; Grant and Gino, 2010), and organizational citizenship behaviors (McCullough et al., 2001; Spence et al., 2013). 
In the sphere of employees' optimal functioning, the above results underline the need to organize training and workshops focused on improving employee gratitude as a factor important for employee well-being. According to previous research, gratitude intervention in clinical samples positively impacts well-being measured by life satisfaction (Boehm et al., 2011) and negative mood reduction (Sheldon and Lyubomirsky, 2006).

At the organizational level, it is important to promote and develop management and leadership based on gratitude (Michie, 2009) among leaders being the personification of organization (Levinson, 1965), as a positive factor for creating and shaping organizational culture based on gratitude. Appreciative leaders who foster a culture of gratitude can create a positive climate in their teams.

Based on these promising findings, future research should focus on the relationship between gratitude toward the organization and efficiency, productivity, and prosocial organizational behaviors in different organizational contexts. At the organizational level, future research could verify the role of employee gratitude toward the organization for shaping organizational culture based on gratitude (see Fehr et al., 2017) and the role of social learning in this process.

The next step in the works on the Gratitude Toward the Organization Scale should be its standardization implemented by means of conducting studies on the general population of employees in Poland, along with the verification of psychometric properties of this measure in another cultural context.

\section{References}

Adler, M.G. and Fagley, N.S. (2005). Appreciation: Individual differences in finding value and meaning as a unique predictor of subjective well-being. Journal of Personality, 73,79-114.

https://doi.org/10.1111/j.1467-6494.2004.00305.x.

Berger, F.R. (1975). Gratitude. Ethics, 85, 198-209. https://doi.org/10.1086/291969.

Blau, P. (1964). Exchange and power in social life. New York: Wiley. https://doi.org/10.2307/2574842.

Boehm, J.K., Lyubomirsky, S. and Sheldon, K.M. (2011). A longitudinal experimental study comparing the effectiveness of happiness-enhancing strategies in Anglo Americans and Asian Americans. Cognition and Emotion, 25(7), 1152-1167.

https://doi.org/10.1080/02699931.2010.541227.

Buksik, D. (2002). Moral and religious attitudes in psychology. Seminare, 18, 475-488.

Byrne, B.M. (1994). Structural equation modeling with EQS and EQS/Windows. Thousand Oaks: SAGE Publications. https://doi.org/10.1177/014662169401800208.

Di Fabio, A., Palazzeschi, L. and Bucci, O. (2017). Gratitude in organizations: A contribution for healthy organizational contexts. Frontiers in Psychology, 8, 1-6. https://doi.org/10.3389/fpsyg.2017.02025. 
Dik, B.J., Duffy, R.D., Allan, B.A., O’Donnell, M.B., Shim, Y. and Steger, M.F. (2014). Purpose and meaning in career development applications. Counseling Psychology, 43, 558-585. https://doi.org/10.1177/0011000014546872.

Dunn, J.A. and Schweitzer, M.E. (2005). Feeling and believing: The influence of emotion on trust. Journal of Personality and Social Psychology, 88(5), 736-748. https://doi.org/10.1037/0022-3514.88.5.736.

Eisenberger, R., Hungtington, R., Hutchison, S. and Sowa, D. (1986). Perceived Organizational Support. Journal of Applied Psychology, 71(3), 500-507. https://doi.org/10.1037/0021-9010.71.3.500.

Emmons, R.A. and Crumpler, C.A. (2000). Gratitude as human strength: Appraising the evidence. Journal of Social and Clinical Psychology, 19, 56-69. https://doi.org/10.1521/jscp.2000.19.1.56.

Emmons, R.A. and Kneezel, T.E. (2005). Giving thanks: spiritual and religious correlates of gratitude. Journal of Psychology and Christianity, 24, 140-148. https://doi.org/10.1080/17439760.2011.596557.

Emmons, R.A. and McCullough, M.E. (2003). Counting blessings versus burdens: An experimental investigation of gratitude and subjective well-being in daily life. Journal of Personality and Social Psychology, 84(2), 377-389. https://doi.org/10.1037/0022-3514.84.2.377.

Fehr, R., Fulmer, A., Awtrey, E. and Miller, J.A. (2017). The grateful workplace: A multilevel model of gratitude in organizations. Academy of Management Review, 42(2), 361-381. https://doi.org/10.5465/amr.2014.0374.

Friedman, P.H. (1989). Creating well-being: The healing path to love, peace, self-esteem and happiness. Saratoga, CA: R and E Publishers.

Fredrickson, B.L. (2001). The role of positive emotions in positive psychology: The broaden and build theory of positive emotions. American Psychologist, 56(3), 218-226, https://doi.org/10.1037/0003-066X.56.3.218.

Fredrickson, B.L. (2004). Gratitude, Like Other Positive Emotions, Broadens and Builds. In: R.A. Emmons and M.E. McCullough (eds.), Series in affective science. The psychology of gratitude. Oxford University Press. https://doi.org/10.1093/acprof:oso/9780195150100.003.0008.

Gouldner, A.W. (1960). The norm of reciprocity: A preliminary statement. American Sociological Review, 25(2), 161-178. https://doi.org/10.2307/2092623.

Grant, A.M. and Gino, F. (2010). A little thanks goes a long way: explaining why gratitude expressions motivate prosocial behavior. Journal of Personality and Social Psychology, 98, 946-955. https://doi.org/10.1037/a0017935.

Grant, A.M. and Wrzesniewski, A. (2010). I won't let you down... or will I? Core self-evaluations, other-orientation, anticipated guilt and gratitude, and job performance. Journal of Applied Psychology, 95, 108-121. https://doi.org/10.1037/a0017974.

Harned, D.B. (1997). Patience: How we wait upon the world. Cambridge, MA: Cowley.

$\mathrm{Hu}, \mathrm{X}$. and Kaplan, S. (2014). Is "feeling good" good enough? Differentiating discrete positive emotions at work. Journal of Organizational Behaviour, 36, 39-58. https://doi.org/10.1002/job.1941.

Kępiński, A. (1987). Anxiety. Warsaw: Państwowy Zakład Wydawnictw Lekarskich. Kossakowska, M. i Kwiatek, P. (2014). Polish adaptation of the questionnaire to study gratitude GQ-6. Przeglad Psychologiczny, 57(4), 503-514.

Krause, N. and Hayward, R.D. (2015). Humility, compassion, and gratitude to God: Assessing the relationships among key religious virtues. Psychology of Religion and Spirituality, 7(3), 192-204. https://doi.org/10.1037/rel0000028.

Lance, C.E., Lautenschlager, G.T., Sloan, C.E. and Varca, P.E. (1989). A comparison between bottom-up, top-down and bi-directional models of relationships between global and life facet satisfaction. Journal of Personality, 57(3), 601-624. https://doi.org/10.1111/j.1467-6494.1989.tb00565.x. 
Levinson, H. (1965). Reciprocation: The relationship between man and organization. Administrative Science Quarterly, 9(4), 370-390. https://doi.org/10.2307/2391032.

Maslow, A. (1968). Toward a psychology of being. New York: D. Van Nostrand Company. https://doi.org/10.1037/10793-000.

McCullough, M.E., Emmons, R.A. and Tsang, J.A. (2002). The grateful disposition: a conceptual and empirical topography. Journal of Personality and Social Psychology, 82, 112-127. https://doi.org/10.1037/0022-3514.82.1.112.

McCullough, M.E., Kilpatrick, S., Emmons, R.A. and Larson, D. (2001). Is gratitude a moral affect? Psychological Bulletin, 127, 249-266. https://doi.org/10.1037/0033-2909.127.2.249.

Meilaender, G.C. (1984). The theory and practice of virtue. Notre Dame, IN: University of Notre Dame Press. https://doi.org/10.1017/CBO9781316156766.010.

Michie, S. (2009). Pride and gratitude: how positive emotions influence the prosocial behaviors of organizational leaders. Journal of Leadership \& Organizational Studies, 15, 393-403. https://doi.org/10.1177/1548051809333338.

Morgan, B., Gulliford, L. and Kristjánsson, K. (2017). A new approach to measuring moral virtues: the multi-component gratitude measure. Personality and Individual Differences, 107, 179-189. https://doi.org/10.1016/j.paid.2016.11.044.

Müceldili, B., Erdil, O., Akgün, A.E., and Keskin, H. (2015). Collective gratitude: positive organizational scholarship perspective. International Business Research, 8, 92-102. https://doi.org/10.3389/fpsyg.2017.02025.

Park, N., Peterson, C. and Seligman, M.E.P. (2004). Strengths of character and well-being. Journal of Social and Clinical Psychology, 23(5), 603-609. https://doi.org/10.1521/jscp.23.5.603.50748.

Schimmel, S. (1997). The seven deadly sins: Jewish, Christian, and classical reflections on human psychology. New York: Oxford University Press.

Seligman, M.E.P. (2002). Authentic happiness. New York: Free Press.

Sheldon, K.M. and Lyubomirsky, S. (2006). How to increase and sustain positive emotion: The effects of expressing gratitude and visualizing best possible selves. The Journal of Positive Psychology, 1(2), 73-82. https://doi.org/10.1080/17439760500510676.

Simmel, G. (1950). The sociology of Georg Simmel. Glencoe, IL: Free Press. https://doi.org/10.2307/2226628.

Smith, A. (1976). The theory of moral sentiments (6th ed.). Oxford: Clarendon. https://doi.org/10.1017/CBO9780511800153.005.

Solomon, R.C. (1977). The passions. Garden City, NY: Anchor Books.

Spence, J.R., Brown, D.J., Keeping, L.M. and Lian, H. (2013). Helpful today, but not tomorrow? Feeling grateful as a predictor of daily organizational citizenship behaviors. Personnel Psychology, 67, 705-738. https://doi.org/10.1111/peps.12051.

Steiger, J.H. (1990). Structural model evaluation and modification: An interval estimation approach. Multivariate Behavioral Research, 25(2), 173-180. https://doi.org/10.1207/s15327906mbr2502_4.

Teigen, K.H. (1997). Luck, envy, and gratitude: It could have been different. Scandinavian Journal of Psychology, 38, 313-323. https://doi.org/10.1111/1467-9450.00041.

Van Cappellen, P., Toth-Gauthier, M., Saroglou, V. and Fredrickson, B. (2016). Religion and well-being: The mediating role of positive emotions. Journal of Happiness Studies, 17, 485-505. https://doi.org/10.1007/s10902-014-9605-5.

Watkins, P.C., Woodward, K., Stone, T. and Kolts, R.L. (2003). Gratitude and happiness: development of a measure of gratitude, and relationships with subjective well-being. Social Behavior and Personality, 31(5), 431-452. https://doi.org/10.2224/sbp.2003.31.5.431. 
Wnuk, M. (2017a). Polish version of Organizational Justice Scale. Edukacja Ekonomistów i Menedżerów. Problemy. Innowacje. Projekty, 3, 37-56.

Wnuk, M. (2017b), Psychometric properties of the polish version of Organizational Commitment Scale. Organizacja i Kierowanie, 3(177), 109-125.

Wnuk, M. (2017c). Verification of reliability as well as internal and theoretical consistency polish version of the Survey of Perceived Organizational Support. Zarzqdzanie Zasobami Ludzkimi, 2(115), 91-103.

Wnuk, M. (2017d). Gratitude and loyalty toward the organization as significant factors in the employee-organization exchange. Zarzqdzanie Zasobami Ludzkimi, 5(118), 55-73.

Wnuk, M. (2018). Spirituality and job satisfaction. Mediating role of stress, gratitude toward the organization and trust in supervisor. Moderating role of religious practices. Modern Management Review, 23(4), 277-296. http://doi.prz.edu.pl/pl/pdf/zim/377.

Wnuk, M. (2019). Social exchange as a significant factor for shaping employees attitude toward the organization. Organizacja i Kierowanie, 3, 57-71. 